\title{
Caring for the collective \\ Biopower and agential subjectification in wildlife conservation
}

\section{Krithika Srinivasan}

\begin{abstract}
This paper explores turtle conservation in Odisha, India, to map the complicated manners in which animal well-being is pursued in the contemporary world. Using insights from Foucault's work on biopolitics, it offers an account of conservation as population politics, questioning the entanglement of harm and care that infuses this space of more-thanhuman social change. In doing this, the paper elaborates the concept of agential subjectification in order to track the mechanisms that underlie the asymmetric circulation of biopower in human-animal interactions and to develop Foucauldian scholarship for the examination of present-day manifestations of the 'will to improve'.
\end{abstract}

Keywords: conservation, environment, Foucault, animal, biopower, more-than-human

\section{Introduction}

A recurrent theme in Michel Foucault's oeuvre has to do with the importance of attending to the working of power in spaces of change and reform (Foucault, 1980a). Taking inspiration from this, in this paper I ask what present-day processes of 'more-than-human' social change indicate about shifting forms of power in human-nonhuman (animal) relationships. I pursue this broad question by examining one key domain of more-than-human activism: wildlife conservation. Specifically, I explore Olive Ridley turtle conservation in Odisha, India, using this case to map the complexities of caring for and protecting nonhuman animals in the contemporary world and to track what such efforts might indicate about the changing ways in which humans impinge upon the lives of their nonhuman co-habitants of the planet ${ }^{3}$.

There are two reasons why Foucauldian scholarship is especially useful for the study of conservation. First, Foucault's work on spaces of social change and 'improvement' (e.g., the medicalisation of madness, penal reform) urges attention to the subtle ways in which power operates in formations of care (Foucault, 1980a; Philo, 2012). Of particular value is Foucault's conceptualization of biopower: a mode of power that is "bent on generating forces, making them grow, and ordering them" (2008, page 136), but that nonetheless is not necessarily benign in its effects. While Foucault was interested only in intra-human relationships, the focus on life and its flourishing running through his writings on biopower indicate their applicability to all sentient beings, especially animals (Hannah 2011, pages. 9, 11). Thus, using a Foucauldian lens to study the conservationist domain of care where humans seek to promote the flourishing of animals, this paper questions the self-evidence of conservationist

\footnotetext{
${ }^{1}$ Srinivasan K, 2014, "Caring for the collective: biopower and agential subjectification in wildlife conservation" Environment and Planning D: Society and Space 32(3) $501-517$

2 Srinivasan K, 2014. The definitive, peer-reviewed and edited version of this article is published in Environment and Planning D: Society and Space, 32(3), 501 - 517 doi:10.1068/d13101p

${ }^{3}$ While humans and nonhumans affect each other's lives in asymmetric manners, this paper is interested in how humans affect animal lives.
} 
discourses and practices of improvement, inquiring into the veiled ways in which power infuses human-animal interactions.

Second, Foucault clearly demonstrates the importance of exploring discourse as a site of power with inherently "physical, material, corporal (sic)" effects (1980a, page 57). As Philo observes, while Foucault's units of analysis were discourses, "his reasoning is predicated on bodies beyond discourses" (2012, page 506, emphasis as in original). Foucault's writings are thus helpful in tracing the intricate connections between discursive activity and its morethan-discursive counterparts. Such connections are significant as the exercise of power in human-animal relations is usually corporeal even when it is embedded in human discursive processes.

In other ways, however, Foucault's legacy proves inadequate when trying to understand flows of power that affect nonhuman animals. This is particularly with regard to the mechanisms that underlie the working of biopower. Existing formulations of these have focused mainly on subjectification as self-governance (e.g., Agrawal, 2005; Rabinow and Rose, 2006) and do not satisfactorily account for the operation of biopower in human-animal interactions (cf. Holloway and Morris, 2012). This paper addresses this lacuna by theorizing the concept of 'agential subjectification' to explain how biopower in more-than-human contexts can be driven by subjectification in those (humans) acting for and on behalf of animals (Srinivasan, 2013).

In essence, the paper looks into the intersection of conservation discourse and practice with the material lives of the turtles. In doing this, it simultaneously engages with conservation (Brockington and Duffy, 2010; Shahabuddin and Rangarajan, 2007) and animal/more-thanhuman geographies (Wolch and Emel, 1998). From the former, it takes insights relating to the value of attending to the discursive construction of nature and to wider socio-political processes. With the latter, it shares an interest in animals as subjects of ethical and political concern. This integration enables the recognition that human-animal relations in general, and conservation in particular, are shaped not just by personal motivations but also by socio-political influences, and allows for the direction of attention to those aspects of these relationships that are substantially driven by human decision-making (Srinivasan, 2013). To this end, the paper works with Foucault's scholarship on biopower and governmentality to chart the linkages between the socio-political context, human discursive activity and the embodied politics of intervening on, in, and for turtle life.

The paper draws on interview and documentary materials gathered over the course of field research on Olive Ridley conservation in Odisha. With these materials, I undertake a close examination of the manners in which the conservation dispositif ${ }^{4}$ addresses - and is also shaped by - various socio-political challenges. In dialogue with Foucault's works, I then offer

\footnotetext{
${ }^{4}$ Dispositif refers to a set of discursive and more-than-discursive practices that are particular to a social domain (e.g., the penal system) (Bussolini, 2010; Deleuze, 1992; Foucault, 1980c). Here, the ensemble of truth discourses and material practices that go under the rubric of Olive Ridley conservation can be understood as constituting a dispositif.
} 
an account of conservation as population politics and examine the associated entanglement of harm and care in order to complicate the predominant conservationist focus on nonhuman collectives of various kinds - species, populations, ecosystems. Through these analyses, I elaborate processes of agential subjectification that underlie the circulation of biopower in domains of care and reform. In all, this paper seeks to engage with questions concerning the shape, form and consequences of conservation for its subject-objects of concern - the animals themselves - and with questions concerning the relevance of Foucauldian scholarship for understanding the 'will to improve', whether directed at humans or animals, in the contemporary world (Dillon and Reid, 2009; Li, 2007).

\section{Turtle conservation in Odisha}

Olive Ridleys are listed as 'Vulnerable' by the IUCN (International Union for the Conservation of Nature). These marine turtles migrate large distances annually, from feeding grounds in the open seas to selected coastal waters and beaches where they nest, either solitarily, or in mass nesting events called arribadas, including in the state of Odisha, India, at Gahirmatha beach and the Rushikulya and Devi river mouths. Olive Ridleys in Odisha, as in other parts of the world, face threats from development activities and fishing. Turtles drown when trapped in trawl and gill nets as they need to surface for air every half hour or so; these nets remain underwater for significantly longer periods. By the 1990s, at least 10,000-20,000 turtles were dying in the area annually as fisheries by-catch. Development activities in the region affect the turtles because of pollution, habitat destruction, and artificial illumination (Shanker, 2007). These have most recently taken the form of a mega-port project which has come up near the sanctuary.

Olive Ridleys in Odisha are offered legal protections by the Gahirmatha Marine Sanctuary and under the Indian Wildlife Protection Act and the Orissa Marine Fisheries Regulation Act. These protections have come into being because of the efforts of conservation groups working here. They have also attracted a fair deal of opposition. The regulation of fishing for conservationist objectives has pitted fishing communities against the forest department and conservationists because of impacts on livelihoods, harassment by forest officials and other problems commonly seen in 'fortress' conservation (Sridhar and Shanker, 2007). A fishing union leader ${ }^{5}$ even accused environmental groups of practising neo-colonial conservation (Adams and Mulligan, 2003): "they are getting foreign money to conserve turtles; they are hindering the development of fishermen as per the wishes of foreign interests (sic)".

Similarly, an anti-port campaign led by Greenpeace India and other conservation groups has evoked counter-reactions from the port company and the state government (Greenpeace, 2009). The port, designed to handle mineral cargo, is meant to service the states of Odisha, Jharkhand and West Bengal which are locations of some of India's richest mineral deposits. The port company has accused the campaign of being "a means for one-upmanship and pecuniary purposes" (DPCL, 2010, page 2), and in 2007, the state government blacklisted Greenpeace for impeding the state's economic development (Anon, 2007). The anti-port

\footnotetext{
${ }^{5}$ Interview, 2010.
} 
campaign was not successful in stopping the project. But it did push the Dhamra Port Company Limited (DPCL) into hiring IUCN to help them implement a mitigation programme.

On the surface, these controversies around turtle conservation in Odisha well exemplify the classic conflict between development, local livelihoods, and environmental protection (Campbell, 2007; Kothari, 2009). Nonetheless, as has been observed in other conservation sites (Brockington and Scholfield, 2010), conservation groups in Odisha, far from focusing solely on protecting nonhuman interests, are in agreement that local livelihoods and regional development are critical concerns that need to be taken on board. IUCN sees its partnership with DPCL as "safeguarding both biological diversity and the needs of people" (Dublin, 2008, page 26). Greenpeace, despite driving the anti-port campaign, records its belief "that economic growth and infrastructure can go hand in hand with protection of the environment" (Greenpeace, 2007b, page 3). Similarly, conservation organizations in the region are involved in many programmes that address the needs of local human communities (Greenpeace, 2007b; Wright, Mohanty et al., 2001). As a local conservationist observes, " conservation projects necessarily have to include human livelihood programmes." This is not to say that there aren't differences in the extent to which different conservationists emphasize various human concerns ${ }^{7}$. But in general, as is seen across the world, there is overarching consensus about the significance of human interests and needs, and the importance of addressing them alongside conservationist objectives (Mansfield, 2009; Paquet and Darimont, 2010).

In essence, conservation in Odisha is shaped by two sets of normative objectives - humanoriented and animal-oriented - which are not necessarily mutually compatible. As discussed further, this translates into what are seen as win-win conservation approaches that seek to protect turtles as a species whilst simultaneously addressing human interests related to regional development and local livelihoods. What I will show is that these competing sets of normative objectives render turtle conservation a fundamentally biopolitical endeavour. In order to do this, I draw on four characteristics of biopower that Foucault flags in his writings (Foucault, 2003, 2008, 2009). Biopower:

- regulates, works alongside, and in synergy with existing rhythms in the 'biosocial collectivity'8 (Rabinow and Rose, 2006).

- is directed at the fostering of populations/collectives.

- is characterized by an entanglement of harm and care.

- is underpinned by subjectification.

\footnotetext{
${ }^{6}$ Interview, 2010.

${ }^{7}$ For instance, the IUCN partnership with DPCL was opposed by some conservation groups; Greenpeace and other groups are, in general, more supportive of the concerns of fishing communities than of the port project (MTN, 2008).

${ }^{8}$ I use this term here to refer to more-than-human groupings comprising both humans and animals (Holloway and Morris, 2012).
} 


\section{Biopolitical regulation}

In contrast to sovereign techniques that lay down totalitarian laws and prohibitions and function through logics of overt violence, biopower or the power "to make live" displays regulatory contours (Foucault, 2003, page 241). Foucault notes that such regulation in the name of care is carried out through various interventions which work alongside existing rhythms in the biosocial collectivity rather than against them: they are in synergy with "natural processes...[they] take them into account, get them to work... work with them"(2009, page 352). As explained below, the turtle conservation dispositif is characterized by a similar modulatory approach which is in synergy with ongoing processes in the human-animal biosocial collectivity, and which works through interventions that are in keeping with the limits and possibilities emerging from the socio-political context outlined above.

The Gahirmatha Marine Sanctuary is an important conservation intervention: some physical space is set aside for the turtles (and other nonhuman life-forms) to facilitate life processes such as the reproductive activities of mating and nesting. The sanctuary regulations do not take the form of sovereign, blanket prohibitions on fishing in the region. They instead modulate fishing, differentiating between types of boats and nets vis-à-vis their impacts on the turtles. Non-motorised boats are allowed 'innocent passage' ${ }^{9}$ through the sanctuary core, whereas in the buffer zone, fishing is allowed with monofilament nets in boats with engine capacity of less than $10 \mathrm{hp}$. In other parts of the Odisha coast, turtles are afforded protections by the Orissa Marine Fisheries Regulation Act (OMFRA). These regulations are similarly based on the varied impacts that different fishing practices have on turtles (Sankaran, Sridhar et al., 2005).

With respect to the port project, measures introduced by IUCN seek to protect the turtles by mitigating impacts of port-related dredging and lighting. All dredgers used in the port project were installed with turtle deflectors, and around thirty 'turtle-friendly' lights had been installed at the time of fieldwork. All port lights were to be eventually converted, and construction lights to be turned off during the hatching season.

All these conservation interventions operate so as to meet the twin normative objectives of human and turtle wellbeing. Rather than prohibiting activities that are harmful to the turtles (such as trawling, port construction), they work with and manage ongoing interactions and processes in the human-animal biosocial collectivity. No sovereign ban on port construction and operation, no dredging windows (a pause in dredging during the breeding season) but rather a working with that modifies and regulates existing activities through the use of deflectors and turtle-friendly lights. Similarly, the sanctuary and OMFRA regulations are tailored to particular types of boats, nets, seasons and locations and take into account existing activities and processes in the biosocial collectivity (Foucault, 2009). They conform to the biopolitical mould in that government is carried out by "the means of

\footnotetext{
${ }_{9}^{9}$ Permission to pass through but not to engage in extractive activities.
} 
specific, detailed regulation and decree" rather than general prohibitions (Gordon 1991, p.10).

An off-shoot of this biopolitical modulation is that none of these interventions completely eliminates harmful human impacts on the turtles - they only try to reduce and regulate the numbers of affected turtles. Turtles continue to die in trawl and gill nets (Shanker, 2007), turtle excluder devices are used as makeshift television antennae, and the deflectors don't address the destruction of local food chains by the dumping of dredged material (Greenpeace, 2007a). Similarly, the turtle-friendly lighting installed in the port is based on research that shows that some kinds of light sources are less harmful (IUCN, 2008) than others (rather than with having no impacts); it also doesn't address threats posed by lighting in secondary development associated with the port. Such biopolitical regulation that allows for a degree of harm is made necessary because turtle conservation cannot be solely about protecting the turtles but also has to address various human-oriented normative objectives; sovereign techniques such as the cancellation of the port project or a complete ban on mechanized fishing fall outside the bounds of possibility. These win-win governmentalities are seen not only in conservation in Odisha but also in other spaces of environmental action that are shaped by neoliberal forces, and are indeed a characteristic of neoliberalism more generally (Brockington \& Duffy, 2010; Fletcher, 2010; Hudson, 2011; Mansfield, 2009).

\section{Population}

Biopower and associated governmental logics are exercised in the name of "the welfare of the population, the improvement of its condition" (Foucault, 1991a, page 100). The population, or the collective, is the main target - the subject-object - of biopolitical care. Biopolitical interventions might work through individuals $(\mathrm{e}, \mathrm{g}$, turtle deflectors push individual turtles out of the way of the dredger) - and in fact, pastoral power ${ }^{10}$ involves individualized practices of care - but the overarching concern is with the fostering of the collective (Braverman, 2013; Foucault, 2009).

Foucault's discussions of 'population' were rooted in particular empirical and historical contexts; he was interested in human populations of nation-states. This raises the question of whether the biopolitical concept of population can be applied to nonhuman animals. However, it is important to remember that Foucault was clear that he wanted his writings to be seen as "trails to be followed", rather than theoretical frameworks to be adopted or rejected as a whole (Foucault, 1980e, page 79). This conceptual generosity on Foucault's part has enabled scholars from a range of fields to selectively apply and modify his ideas to reflect on issues - such as gender - that Foucault never did contemplate (Sawicki, 1994).

It is therefore not surprising that Foucault's writings, especially on biopolitics with its emphasis on the care of life (Hannah 2011), have been used, despite their apparent speciesblindness, to theorize human-environment/animal interactions (Holloway and Morris, 2012;

\footnotetext{
${ }^{10}$ Pastoral power can be understood as part of the complex of non-sovereign modalities of power that Foucault writes about.
} 
Youatt 2008). This has gone alongside the increasing incorporation of various nonhuman life-forms into the realm of the political - this is seen not only in political action around more-than-human issues, but also more obviously in national and international legislations that protect and regulate animal life, whether zoo and farm animals in the United States (Braverman, 2013; Hudson, 2011), or Olive Ridley turtles in India.

In using the biopolitical framework to critically analyse human-animal relationships, such work has expanded Foucault's purely human conceptualisation of the biopolitical 'population' to discuss nonhuman and human-nonhuman collectives of varying kinds breeds (Holloway and Morris, 2012), genotypes (Braverman 2013), species (Chrulew, 2012); spatially defined animal groups/populations (Srinivasan 2013); and even 'biodiversity' (Youatt 2008). Building on these, this paper explores the insights that emerge from application of the biopolitical concept of 'population' to Olive Ridley turtles. It examines what this concept can offer to the critical analysis of conservation, and also reflects on some differences between human and animal populations when it comes to the functioning of biopower.

It is widely recognized that wildlife conservation is "concerned with populations and habitats" (Paquet and Darimont, 2010). The turtle conservation dispositif is no different, and engages with these animals either as species or regional populations (Shanker, Pandav et al., 2003). In the words of an environmentalist ${ }^{11}$, "it isn't about the life of an individual turtle or how it is treated." Turtle mortality matters only insofar as it affects the population as a whole. As a forest department official muses ${ }^{12}$ : "There are numerous turtles...casualty numbers may be high, but rate might be low... 10-15,000 deaths might be nothing." Hence, concern for turtles is directed at their survival as a whole, as a population in the long run, rather than the survival or wellbeing of any particular individual that is currently alive.

Even when conservation interventions (e.g., turtle deflectors) work through individual turtles, the overarching concern is with the fostering of the turtle population. The individual becomes chiefly a means to an end. Indeed, articulations of concern for individual turtles are dismissed by conservationists as "founded on soapboxes" (Shanker, 2002, page 3). The focus on the wellbeing of the turtle populations and not turtle individuals is also evident in discussions around what constitutes a population that is worthy of being protected. If the existing turtle population is too small, protective action is considered unnecessary and even counterproductive (Shanker, 2001).

The concern for turtle populations is equally extended to a more abstract level - that of the ecosystem. Olive Ridley turtles are seen as a flagship species which can be used to gather support for the protection of ecosystems (Frazier, 2005). Here, turtle flourishing becomes important because of its interconnectedness with the flourishing of the human-animal biosocial collectivity (Youatt, 2008). On the whole then, Olive Ridley conservation in Odisha

\footnotetext{
${ }^{11}$ Interview, 2010.

12 Interview, 2010.
} 
primarily constitutes "a politics concerned with subjects as members of a population" (Gordon, 1991, page 5). While individuals are occasionally considered by the conservation dispositif (Jepson and Canney, 2003), by and large, collective ontologies or "higher levels of organisation" such as "populations, species, and ecosystems" occupy privileged positions and are taken for granted as the appropriate locus of concern and care (Paquet and Darimont, 2010, page 84 .

This biopolitical focus on the fostering of the collective in and of itself is not particularly remarkable. What is of interest, however, is an associated entanglement of harm and care.

\section{Harm and care}

Even though biopower is directed at fostering life, violence and harm do not disappear; rather, they are rationalized as necessary for the flourishing of the population: "on behalf of the existence of everyone...in the name of life necessity" (Foucault, 2008a, page 137). In other words, an entanglement of harm and care goes with the sacrificial logic of population: individuals can be harmfully intervened on in the name of universal wellbeing. Under biopolitical regimes, the population is much more than the sum of the individuals constituting it; it forms a distinct aspect of social reality in itself. Individuals diminish in ethical and political significance and can be shaped, and even sacrificed for collective wellbeing (Foucault, 2009, pages 42-44; Gordon, 1991, page 10).

When it comes to conservation in the contemporary world, the protection of "species and populations often trumps all other values, including the welfare of individuals" (Paquet and Darimont, 2010, page 84). Individuals are seen as representatives of species (Bear, 2011), and as Braverman (2013, page 22) points out, even those conservationist spaces (such as zoos) that display focused care for indviduals, "more readily sacrifice the individual animal for the benefit of the flock, rather than the other way around."

\section{Calculations of permissible harm}

The sacrificial logic of population is seen in the "calculated management of life" (Foucault, 2008a, page 140) where regulation involves estimations of the value of life-forms: biopolitical interventions "qualify, measure, appraise and hierarchize" (Foucault, 2008a, page 144). Such calculations involve judgments about how individuals can be best deployed, intervened upon, or sacrificed so as to ensure the flourishing of the population. They also involve appraisals of "a bandwidth of the acceptable", like in the case of biopolitical mechanisms that address public health by calculating normal morbidity and mortality to keep disease within certain limits or in the case of neoliberal social control mechanisms that seek to keep crime under certain levels (Foucault, 2008b, page 256; Foucault, 2009, page 6).

Ideas of acceptable harm circulate widely in the conservation dispositif which calculates that a certain amount of harm to turtle individuals can be allowed to happen. As one 
environmentalist asserts ${ }^{13}$ : "we should come up with an acceptable figure for mortality." Such figures have been developed in other regions, and are seen as models for turtle conservation in Odisha. For instance, the National Oceanic and Atmospheric Administration in the United States sets annual 'turtle take allowances' that determine how many turtles can be killed before it is considered a harm to the particular species/population (IUCN, 2009). In Odisha, the IUCN-instituted conservation intervention of turtle deflectors incorporates a similar turtle take allowance (IUCN, 2007). Turtle deaths due to dredging start to matter only if they exceed this predetermined allowance.

Calculations of permissible harm underlie the sanctuary and the OMFRA regulations as well. The strictest fishing restrictions are in the core area of the sanctuary where turtle density is the highest. At Rushikulya and Devi, during the nesting season, non-motorised craft are allowed within five kilometres of the coast; motorised boats with small mesh nets that are less than 300 metres long can fish beyond five kilometres; mechanised gill netters and trawlers are allowed beyond twenty kilometres (Sankaran, Sridhar et al., 2005). While turtle densities are not as high at these distances, Olive Ridleys continue to get caught (accidentally) and killed in fishing nets: the "enforcement of nearshore bans seems to have had very little impact with numbers of dead turtles remaining at around 10,000 per year" (Shanker, 2007, page 104). Thus, all these conservation protections are bound up with ideas of what level of harm to turtles is permissible.

Sustainable harvesting of turtle eggs and meat (Campbell, 2007; cf. Rosser and LeaderWilliams, 2010) while not in practice at the time of fieldwork, is an enthusiastically promoted conservation intervention that is equally founded on calculations of permissible harm. Sustainable harvesting intervenes harmfully on turtle individuals in the name of population wellbeing (and that of the human-animal biosocial collectivity). Conservationists estimate that the turtle population along the Orissa coast could "sustain the exploitation of a few hundred or a few thousand adult turtles every year" (Shanker, 2003), making it possible to kill some turtles or remove some eggs without harming the population.

\section{Harming to protect}

In sustainable harvesting, calculations of permissible harm come together with the logic of harming to protect. Conservationists in Odisha explain that there is no current local demand for turtle eggs or meat. But sustainable harvesting is recommended in the hope that it will create new incentives for conservation and provide the turtles with "a stronger representation at the negotiating table" (Mrosovsky, 2008, page 14), i.e., the sacrifice of individual turtles will gather support for the conservation of turtles as a population. As Shanker (2003) argues while discussing Olive Ridley conservation in Orissa, "sustainable utilisation can be a powerful tool in motivating communities to conserve a resource [the turtles]." Such sacrifice is a key biopolitical strategy, which functions by "distributing the living in the domain of value and utility" (Foucault, 2008a, page 144). While there are debates around sustainable harvesting as a conservation strategy, these tend to be centred

\footnotetext{
${ }^{13}$ Interview, 2010.
} 
on managerial questions of whether populations can tolerate such harvesting (cf. Rosser and Leader-Williams, 2010). So in general, the view is that if some turtles are of more value to the turtle population dead rather than alive, then this enhanced utility ought to be used to pursue the biopolitical goal of fostering the population.

The entanglement of harm and care is also seen in spaces of conservation research. The exercise of biopolitical power goes alongside the creation and deployment of formal knowledge bodies (Foucault, 2009, page 79). In Odisha, as in many other places, scientific knowledge is seen as an essential foundation for and component of conservation action (Shanker, Pandav et al., 2003).

While conservation research can be observational, it can also be invasive, intervening harmfully in the bodies of individual animals (Bekoff 2013). For instance, Olive Ridleys are commonly tagged for conservation studies. Tagging is usually carried out during nesting, and involves using application pliers to punch through the flesh on the turtle's flippers to insert the metal or plastic tags. Tagging is not painless, can cause abrasions and infections, and make turtles "more susceptible to being accidentally caught in fishing nets" (Anon, 2012). Balazs (1999, pages 8,3) also explains that "healing may not occur if a tag is applied too tightly, or the tag corrodes and releases copper and nickel oxides"; and if immature turtles are tagged, growth makes the flipper "more liable to tearing and loss." Altogether, tagging exemplifies how "where religion once demanded the sacrifice of bodies, knowledge now calls...us to the sacrifice of the subject of knowledge"(Foucault, 1984a, page 96).

Even seemingly non-invasive population censuses (Shanker, Pandav et al., 2003) have the potential to harm. Olive Ridley population censuses are carried out during oviposition. Olive Ridleys choose the darkest nights to nest so as to avoid predators, of which humans are arguably one. Even if the researchers do not have predatory intentions, the turtles have no means of knowing that these humans do not intend harm. Such a situation then has the potential to induce fear and stress in the nesting turtles. Similar issues make conservation education measures such as turtle walks and other ecotourism programmes problematic (Neves, 2010; Bekoff, 2013). These programmes are meant to increase awareness and conservationist interest in members of the public much like zoos are meant to (Braverman, 2013). In all these cases - tagging, censuses, turtle walks - the harm caused to individual turtles is either overlooked or excused as necessary for the protection of the population. This is not unique to turtle conservation in Odisha: conservationists working on other animals and in other regions equally "rationalise suffering of individual animals as being necessary to achieve more important ecological goals of population or species preservation, or even their own research goals" (Paquet and Darimont, 2010, page 87).

It is in these fashions that the biopolitical focus on the collective leads to an interlacing of harm and care in wildlife conservation. This is not to say that the biopolitical focus on the collective is the sole underpinning of such ambiguous entanglements; neither does it necessarily lead to a meshing of care and harm (for example, habitat protection programmes do not always harm individual animals). It is also important to note a key difference 
between human and animal populations when it comes to the entanglement of harm and care: even though calculations of permissible harm and trade-offs between conflicting interests underlie many contemporary discourses on human health and safety and environmental risk (Foucault 2009, 6; Porter and Demeritt 2012), it is much more difficult to rationalize harm to human individuals on the basis of collective human or ecological wellbeing, as is regularly seen in arguments against conservation or development programmes that affect individual humans (Agrawal and Redford, 2009; Khagram, 2004). As discussed later, this difference can be at least partly explained by the ongoing prevalance of human exceptionalism.

The entanglement of harm and care highlights the operation of biopower in turtle conservation, but more crucially, raises the question of how and why these spaces of care and improvement, of more-than-human social change, are infused with such problematic practices and discourses. It raises the question of how and why those who care about the the turtles, i.e., the conservationists, engage in interventions that are by no means benign in their impacts on these animals. It is here that another possible difference ${ }^{14}$ between intra-human and human-animal biopolitics emerges - a difference in processes of subjectification that underlie biopolitical power.

\section{On subjectification}

Subjectification is an important motor of biopower (Rabinow and Rose, 2006). I argue below that biopower in the turtle conservation dispositif is driven by 'agential subjectification' (Srinivasan, 2013). By this, I mean subjectification processes in the conservationists whereby they act upon and for turtles on the basis of truth discourses about turtle flourishing.

Subjectification essentially refers to the process by which individual entities self-govern, i.e., work upon themselves, in accordance to various truth discourses about individual and collective wellbeing (Rabinow and Rose, 2006). Activities related to self-governance may or may not be 'good' for the individual, and might even be harmful. Voluntary participation in vaccination programmes in keeping with truth discourses about health benefits of vaccination is an instance of self-governance that can be beneficial to the individual as well as the population (cf. Allen, 2007). On the other hand, the practice of wearing high heels on the basis of norms about the aesthetic advantages and added authority conferred by heels (Kay, 2012), is an instance of self-governance that is physically harmful to the individual (Lee, Jeong et al., 2001). However, subjectification underlain by norms/truth discourses of care and flourishing has the effect that the valence of specific activities or techniques of selfgovernance remains unconsidered. Subjectification thereby renders subtle the operation of biopower.

\footnotetext{
${ }^{14}$ However, as I go on to argue, this is not a necessary difference between biopolitics in the intrahuman and human-animal domains; rather, the application of the biopolitical schema to animal issues helps clarify the varying manifestations of subjectification in both human and more-than-human relationships.
} 
I have so far shown that turtle conservation in Odisha is permeated with biopower. However, subjectification and self-governance based on anthropogenic truth discourses is hard to explain in animals. It is unlikely that the turtles will choose to be killed on the basis of truth discourses about the benefits of sustainable harvesting. In addressing this problem, I develop work on more-than-human subjectification (Holloway and Morris 2012; Srinivasan, 2013) that contends that subjectification need not occur only in the widely recognized form of self-governance. Subjectification can also take place at the site of the agent (s) of intervention, i.e., those who are deploying particular interventions in order to foster the life and flourishing of certain other life-forms.

I argue below that the process of agential subjectification in the turtle conservation dispositif involves the constitution of certain norms and ontologies of animal wellbeing by the human agents of intervention - the conservationists - who, on the basis of these discourses, act, sometimes with harmful impacts, upon individual animals. It must be emphasized that agential subjectification does not refer to a deliberate effort to disguise harm or ulterior motives with discourses of care. Nor does it refer to situations where the very same practices are based on sovereign rationalities of human wellbeing: harvesting of turtle eggs and meat for purely human interests; tagging for scientific curiosity; or the deaths of turtles in trawl nets and dredger dragheads without any consideration of an acceptable mortality rate. Agential subjectification is rooted in genuine motives of care for the 'Other', i.e., the turtles.

\section{The biopolitical care of populations}

Key to unpacking agential subjectification is the conservationist goal of protecting and enhancing the wellbeing of nonhuman animals at the level of collectives such as populations. As explained below, such an ontological and ethical focus is neither natural nor inevitable but can rather be understood as underpinned by agential subjectification.

Even though conservation discourse is usually presented in terms of instrumental arguments about sustainability, resource management and species survival, a closer examination reveals another sense of right and wrong with regard to how humans relate to turtles. As an environmentalist explained ${ }^{15}$, while scientific evidence about the ecological crisis supports conservation action, it is something else that motivates concern for the environment in general and turtles in specific: "there is an irreducible sense of the value of life." Similarly, "IUCN's mission embraces the inherent values of species..." (Dublin, 2008, page 26). Clearly, the concern here extends beyond an instrumental interest in ecosystem services.

There are also indications that even self-described "analytical" and dispassionate conservationists (Hawk, 2009, page 2) are affected by actual turtle death, and not just species flourishing and extinction: "over 100,000 observed, documented, and recorded sea turtle strandings - dead, bloated, rotting sea turtle carcasses...over the last 10 years"(Hawk, 2009, page 2). Similarly, Lenin (2006, page 30) discusses reports of the suffering of freshwater

\footnotetext{
15 Interview, 2010.
} 
turtles in a meat market during the initial stages of turtle conservation in India: "turtles were caught by harpooning and hooking. The hapless turtles were flipped on their backs and their flippers stitched together with binding wire." She goes on to note that photographs of "the gory ridley sea turtle slaughter on Digha beach...and in the meat markets of Calcutta, shook the public when India Today magazine ran them in the early 1980s." It was following this that the then Prime Minister took action to stop the hunting of sea turtles (Shanker, 2007). Unquestionably then, the suffering of individual turtles, rather than only an abstract concern with species extinction appears to have played a vital role in motivating initial conservation action. Disquiet (usually poorly articulated) about the wellbeing of individual animals have been noted in other contexts as well, and are at the root of as yet marginal discussions about compassionate conservation (Bekoff, 2013).

Yet, as noted earlier, present-day turtle conservation in Odisha, as elsewhere, is directed mainly at populations, species and ecosystems: articulations of concern for individuals are negligible, and where raised, are often dismissed. It is a 'rational' and distant - biopolitical concern for sustainable flourishing of the population (and/or the biosocial collectivity) that endures and occupies centre stage in conservation circles, and not an immediate concern for individual wellbeing (cf. Foucault, 1980d, page 170).

Foucault explains that biopolitical rationalities and interventions often serve strategic functions, and respond to specific socio-political needs (1980c, page 195). However, they usually end up "being accepted at a certain moment as a principal component...an altogether natural, self-evident and indispensable part" of the dispositifs they operate in (Foucault, 1991b, page 75). These remarks are important for this paper as they clarify certain movements in the turtle conservation dispositif.

Specifically, I suggest that the privileging of the population in the context of turtle conservation might initially have arisen from the need to work within particular sociopolitical contexts (cf. Jepson and Canney, 2003). For instance, Shanker explains that concern for individual turtles (which he characterises as an 'animal rights' position) "alienates at least some proportion of the public" (2002, page 2). More significantly, as discussed earlier, conservationists are constantly juggling conflicting normative objectives related to human and turtle wellbeing; they have had to do so even more in recent years because of rapidly ascending (human) development goalposts, whether in the form of the emergence of trawl fishing for export markets or infrastructure projects (cf. Shrivastava and Kothari, 2012). Conservation interventions therefore have to biopolitically modulate processes so that the competing goals of turtle protection as well as human livelihoods and regional development can be simultaneously achieved.

This kind of win-win conservation becomes possible only when turtles are ontologically constructed as populations. In essence, the conceptualization of animal wellbeing at the level of the population allows for individual turtles to be killed by dredging, trawling or harvesting without it being considered 'harm' per se. Thus, human-oriented objectives livelihoods and economic development - are addressed even while turtle wellbeing is 
pursued, ensuring that the turtle conservation dispositif meets the normative demands of socio-political context. By contrast, these conflicting goals cannot be easily addressed if individual turtles are taken into ethical consideration. While the initial privileging of the population/collective over that of the individual might have served unrecognized strategic functions (such as enabling win-win conservation), over time, immersion in the practicalities of conservation leads to the entrenchment and mainstreaming of concepts of turtle population wellbeing. This underlies agential subjectification, and in order to track it, I look to Agrawal's (2005) work on environmental subjects in rural India.

\section{Immersion in governmentalities of care}

Agrawal's (2005, page 199) observation that "the question of subject-formation...is crucially connected to participation and practice" encapsulates his argument that participation by villagers in community forest protection activities leads to the inculcation of environmental norms and creates environmental subjects. Following Agrawal, I argue that in Odisha, the immersion of conservationists in daily practices of win-win conservation that address conflicting normative goals leads to agential subjectification in the form of the more or less unquestioning acceptance and pursuit of turtle wellbeing at the level of the population/collective. Specifically, such immersion leads to the inculcation of humanoriented normative objectives emerging from the socio-political context in those advocating for the turtles. The embedding of these human-oriented norms goes along with the entrenchment of discourses and practices of turtle wellbeing that are directed at the level of the population: this ontological and ethical construction of turtles as populations, as discussed earlier, is necessary for win-win conservation as it allows for individual turtles to be harmed by dredging, tagging, trawling, sustainable harvesting, development etc without it being considered as harm per se as long as the population is not affected.

I suggest that the above process of agential subjectification underpins the dominance of the ontology of population in conservationist concern for turtles. The link between agential subjectification and the privileging of the collective over the individual becomes clear when one notes that this is not necessarily how these animals might themselves view their wellbeing: it is unlikely that individual turtles would be willing to sacrifice their lives and wellbeing in order to ensure the wellbeing of the larger population or species. Contrary to common belief that natural selection (and altruism) in animals is directed at benefiting the 'species', evolutionary biology tells us that natural selection processes have no predetermined outcomes, and that "species as an entity does not answer to selection" (Mayr, 1997, page 2092). In fact, there is no way of telling whether turtles (and most other animals, with some exceptions such as bees and ants) have a conception of themselves as a larger population or as a species, or care about the flourishing of the population or the species (Palmer, 2007; Youatt, 2008, page 401).

'Population' and 'species' are ultimately the products of the human urge to categorize and classify - products of the human imagination in general and academic discourse in particular (Braun, 2000). Nonetheless, the conservation dispositif engages with turtle populations as elements of reality (e.g., Shanker, Pandav et al., 2003), putting forward truth discourses and 
developing techniques of intervention that address turtle population wellbeing as a morally neutral matter of fact (Latour, 2004). This is not to say that these understandings of population are false; it is only to underline that they exemplify how power, through agential subjectification, "promotes and utilises a 'true' knowledge of subjects" (Gordon, 1980, page 237), and enables harmful interventions on individuals in the name of collective wellbeing. This, then, is an example of the power-knowledge nexus in operation (Foucault, 1980e).

\section{Agential subjectification and biopower}

Agential subjectification has a specific purpose to play in the working of biopower, just like subjectification as self-governance does: it addresses and resolves the tension between competing normative objectives related to human and animal flourishing.

Foucault (1980a, 2008) identifies the emergence of biopolitical forms of power in times and spaces of change, where there are tensions between (a) existing practices and norms, and (b) demands for change. For instance, the prevailing rationality for state rule - that of the sustenance and continuance of the sovereign - was undermined by challenges to its selfreferential circularity, and came to be replaced by biopolitical rationalities that focus on the wellbeing of the population.

Similar trajectories can be identified in the context of human-animal interactions. Contemporary more-than-human activism and academic scholarship challenge human moral and political exceptionalism and associated speciesism (Armstrong and Botzler, 2008). Such moves, however, have been confronted with practical difficulties in bringing about significant changes in human attitudes and behaviours with regard to other life-forms. As Paquet and Darimont argue (2010, 79), "short-term" human interests almost always prevail over concerns about the enviroment and wildlife. This is particularly so when it comes to public/soceital ${ }^{16}$ decision-making. For example, the idea of conducting human life without electricity is near-impossible to put into practice. This incapacity for change co-exists with the awareness that the process of generating power is deeply harmful to many components of the nonhuman living world, whether in the case of dams submerging forests and drowning animals, windfarms killing birds, biofuel plantations destroying ecosystems, or oil spills affecting marine life. There is thus deep-seated tension between existing human attitudes and practices that are harmful to nonhuman life and public concern for nonhuman life.

This kind of tension is present in the context of turtle conservation as well: tension between sensitivity to nonhuman wellbeing and the prevailing primacy of human interests. As has been shown throughout this paper, these tensions and competing normative objectives are productive of biopower in the turtle conservation dispositif. Agential subjectification, and the associated conceptualisation of animal wellbeing at the level of the population, function to resolve this tension by translating interventions in nonhuman lives that are interlaced

\footnotetext{
${ }^{16}$ By this I mean public debate, law, activism etc and not micro level or personal concern.
} 
with harm into interventions of care that address the wellbeing and flourishing of the animals - as populations.

It must be emphasised that processes of agential subjectification are not all encompassing or immune to questioning. The anti-port campaign and the ban on intentional hunting of turtles imposed under the Indian Wildlife Protection Act emerge from resistance to agential subjectification, and there are at least some debates within conservationist circles about the privileging of the collective over the individual (Bekoff, 2013). Yet, as Agrawal points out, biopower requires subjectification only "in the form of a general acceptance" of certain norms (2005, page 18). Thus, subjectification can take place even when conservationists might harbour private doubts about the norms that they operate with.

\section{Biopolitics and social change}

This paper has presented an account of the "conceptual and practical operations" implicated in the functioning of the turtle conservation dispositif (Gordon, 1980, page 235). In using Foucault's insights on the power of care to query the endurance and dominance of the notion of population in conservation, I have called attention to an ontological scale - that of the individual animal - that has not been given adequate significance in conservation and environmentalism, and also in mainstream social science scholarship (Bear, 2011).This Foucauldian analysis of conservation discourse and practice, in conjunction with learnings from conservation and more-than-human geographies, therefore demonstrates how ontological politics is tied to ethics. Simultaneously, it takes forward emerging literatures (Wadiwel, 2009) that seek to move beyond the human-centered trajectories of Foucauldian scholarship on environmentalism, and subjectification (Agrawal, 2005; Rutherford, 2007), and responds to Bear's (2011, page 302) suggestion that geographers should "take individual animals seriously."

The above examination of conservation rationalities with a Foucauldian lens is of direct relevance to the arena of conservation practice. Biopolitical concepts and practices deployed in turtle conservation are seen in a variety of contexts, whether the control of alien/invasive species (Warren, 2007); sustainable use (Campbell 2007); ecotourism (Neves, 2010); zoos (Braverman, 2013); or captive and artificial reproduction programmes (Chrulew, 2011). In all these instances, the biopolitical redirection of the ontological and ethical gaze to the population/biosocial collectivity and the consequent invisibility of individual nonhuman life-forms play a role in meeting the competing demands of more-than-human scruples and human self-interest. It might well be that biopolitical interventions such as flexible sanctuary regulations and turtle deflectors are inevitable outcomes of having to function within certain socio-political contexts. Indeed, Foucault observes that mechanisms of biopower usually seem indispensable (Foucault, 1984b, page 249).

However, even compromises made to suit particular socio-political contexts can easily become, through subjectification, entrenched and reconstructed as normal-natural-right or as best practices. This is seen in the description of the sanctuary as an inviolate space that is overly protective of nonhuman interests (Shanker and Kutty, 2005); the promotion of 
sustainable harvesting in a region in which there is no local demand for turtle eggs/meat; and the reconstruction of the very act of intervening through make-do compromises such as deflectors and turtle-friendly lighting as "an exemplary exercise in sustainable development" (IUCN, 2009, page 9). It therefore becomes vital to pay heed to Foucault's insistence on an "unaggressive scepticism which makes it a principle not to regard the point in time where we are now standing as the outcome of a teleological progression" (1980b, page 50).

While Foucault's writings were devoid of any interest in the animal question, this paper has added to an emerging body of scholarship that shows that his ideas can offer useful tools for the examination of contemporary human-animal relationships. Neverthless, the analysis undertaken here has shown that Foucauldian insights cannot be applied wholesale to the animal question. The elaboration of agential subjectification shows how biopower functions differently in human-animal interactions. However, this account is applicable not only to human-nonhuman relationships, but can also be tested in the context of intra-human interactions, especially when it comes to projects of amelioration of the lives of human 'Others', for example, those that target children or adults with cognitive disabilities, or in the case of international development $(\mathrm{Li}, 2007)$. As has been noted elsewhere, harmful power can be seen in spaces of care such as social movements and the academia (Rutherford, 1999). Agential subjectification provides one explanation for how such sites of improvement and progress end up rearticulating and reinforcing longstanding relations of power, and is a concept that enhances prevailing understandings of the modes and mechanisms of biopower.

Conservation is a frontier of social change in more-than-human relationships - it is a space where struggles between what is and what might be, even among those who are pioneering such change, are the most strongly played out. The above examination of turtle conservation in Odisha suggests that biopower emerges during social change. Foucault hinted at this by observing the play of non-sovereign modes of power in sites of transformation and improvement ${ }^{17}$ such as psychiatric institutions, penal reform, and economic development. In all these and other spaces of progress and reform (Li, 2007), there are tensions between existing and emerging ways of thinking and acting that are productive of biopower. Therefore biopower becomes both affirmative and harmful (cf. Hannah, 2011). It is affirmative because it appears in times and spaces of social change where there is an effort to ethically improve Self-Other relationships. At the same time, these ethical imperatives do not arise in a vacuum; they are embedded in older, established ways of being and thinking which can be antagonistic to the efforts to change. This incompatibility inherent in processes of social change, in the intersection of continuity and change, results in biopower and its twin-faced concepts and interventions of entangled harm and care. The analyses undertaken here thus indicate that biopower is simultaneously affirmative and harmful when, or perhaps, because, it arises in sites of social change. These are observations - perhaps hypotheses - that provoke both theoretical and activist reflection, and that open up further

\footnotetext{
${ }^{17}$ Or more accurately, these are not domains of overt domination (even though with the benefit of hindsight we now identify them as non-innocent).
} 
lines of inquiry into the features and forms of non-sovereign modes of power in spaces of care and reform.

Acknowledgements. This paper was made possible by the inputs and help of all those I met during fieldwork in Odisha and elsewhere, especially the conservationists whose fortitude in the face of challenging circumstances I very much admire. The RGS-IBG and the Culture and Animals Foundation provided supplementary funding for the project. Thanks to Matthew Gandy, Aaron Gross, Chris Harker, Steve Hinchliffe, and especially David Demeritt and Rema Srinivasan for valuable feedback - and also to H S Subramoney and Vijay K Nagaraj for much more.

\section{References}

Adams, W M and Mulligan, M eds., 2003 Decolonizing nature: Strategies for conservation in a post-colonial era (Earthscan, London, Sterling: VA).

Agrawal, A, 2005 Environmentality: Technologies of government and the making of subjects (Duke University Press, Durham and London).

Agrawal, A, and Redford, K, 2009 "Conservation and displacement: An overview" Conservation and Society 7 1-10.

Allen, A, 2007 Vaccine: The controversial story of medicine's greatest lifesaver (W W Norton \& Company, Inc., New York).

Anon, 2012, "Flipper tags". http://www.seaturtle.org/tagging/flipper.shtml

Anon, 2007, "Orissa government to initiate legal action against Greenpeace" Orissadiary.com (18/08/2007).

Armstrong, S J and Botzler, R G eds., 2008 The animal ethics reader 2nd edition (Routledge, London and New York).

Balazs, G H, 1999 "Factors to consider in the tagging of sea turtles" In Research and Management Techniques for the Conservation of Sea Turtles Eds. Eckert, K L, Bjorndal, K A, Abreu-Grobois, F A, Donnelly, M IUCN/SSC Marine Turtle Specialist Group Publication No. 4. IUCN, pp 1-9.

Bear, C, 2011, “Being Angelica? Exploring individual animal geographies” Area 43(3) 207-304

Bekoff, M, 2013 Ignoring nature no more: The case for compassionate conservation (The University of Chicago Press, London).

Braun, B, 2000, "Producing vertical territory: Geology and governmentality in late Victorian Canada" Cultural Geographies 7(1) 7-46.

Braverman, I, 2013 Zooland: The institution of captivity (Stanford University Press, Stanford, California).

Brockington, D and Duffy, R, 2010, "Capitalism and conservation: The production and reproduction of biodiversity conservation" Antipode 42(3) 469-484.

Brockington, D and Scholfield, K, 2010, "The conservationist mode of production and conservation NGOs in sub-Saharan Africa" Antipode 42(3) 551-575. 
Bussolini, J, 2010, “What is a dispositive? Foucault Studies 10 85-107.

Campbell, L M, 2007, "Local conservation practice and global discourse: A political ecology of sea turtle conservation" Annals of the Association of American Geographers 92(2) 313-334.

Chrulew, M, 2011, “Managing love and death at the zoo: The biopolitics of endangered species preservation" Australian Humanities Review 50 137-157.

Deleuze, G, 1992, “What is a dispositif? In Michel Foucault, Philosopher Ed T J Armstrong (Harvester Wheatsheaf, New York), pp. 159-168.

Dillon, M, \& Reid, J, 2009, The liberal way of war: Killing to make life live, (Routledge, London and New York).

DPCL, 2010, “Response to GP's activity on websites/blogs post Tata Steel AGM on 27/08/09", Dhamra Port Company Ltd, http://dhamraport.com/download/ResponseonAGMGPFinal.pdf.

Dublin, H T, 2008, "The Dhamra port issue: Some views from the chair of the IUCN SSC" Marine Turtle Newsletter 12126.

Fletcher, R, 2010 “Neoliberal environmentality: Towards a poststructuralist political ecology of the conservation debate" Conservation and Society 8 171-181.

Foucault, M, 1980a, "Body/Power", in Power/Knowledge: Selected interviews and other writings 1972-77: Michel Foucault Ed C Gordon (Pantheon Books, New York), pp 5562.

Foucault, M, 1980b, "Prison talk", in Power/Knowledge: Selected interviews and other writings 1972-77: Michel Foucault Ed C Gordon (Pantheon Books, New York), pp 3754.

Foucault, M, 1980c, “The confession of the flesh", in Power/Knowledge: Selected interviews and other writings 1972-77: Michel Foucault Ed C Gordon (Pantheon Books, New York), pp 194-228.

Foucault, M, 1980d, "The politics of health in the eighteenth century", in Power/Knowledge: Selected interviews and other writings 1972-77: Michel Foucault Ed C Gordon (Pantheon Books, New York), pp 166-182.

Foucault, M, 1980e, "Two lectures", in Power/Knowledge: Selected interviews and other writings 1972-77: Michel Foucault Ed C Gordon (Pantheon Books, New York), pp 78108.

Foucault, M, 1984a, “Nietzsche, genealogy, history", in The Foucault reader: An introduction to Foucault's thought Ed P Rabinow (Penguin Books, London), pp 76-100.

Foucault, M, 1984b, "Space, knowledge and power", in The Foucault reader: An introduction to Foucault's thought Ed P Rabinow (Penguin Books, London).

Foucault, M, 1991a, "Governmentality", in The Foucault effect: Studies in governmentality Eds G Burchell, C Gordon, and P Miller (The University of Chicago Press, Chicago), pp 87-104. 
Foucault, M, 1991b, "Questions of method", in The Foucault effect: Studies in governmentality Eds G Burchell, C Gordon, and P Miller (The University of Chicago Press, Chicago), pp 73-86.

Foucault, M, 2003 Society must be defended: Lectures at the College de France 1975-1976 (Picador, New York).

Foucault, M, 2008a The history of sexuality (Vol. 1): The will to knowledge (Penguin Books, Camberwell).

Foucault, M, 2008b The birth of biopolitics: Lectures at the College de France 1978-79 (Palgrave Macmillan, Basingtoke).

Foucault, M, 2009 Security, territory, population: Lectures at the College de France 1977-78 (Palgrave Macmillan, Basingtoke).

Frazier, J, 2005, "The role of flagship species in interactions between people and the sea" MAST 3(2) 5-38.

Gordon, C, 1980, "Afterword", in Power/Knowledge: Selected interviews and other writings 1972-77: Michel Foucault Ed C Gordon (Pantheon Books, New York), pp 229-260.

Gordon, C, 1991, "Government rationality: An introduction", in The Foucault effect: Studies in governmentality Eds G Burchell, C Gordon, and P Miller (University of Chicago Press, Chicago), pp 1-51.

Greenpeace, 2007a, "Biodiversity assessment of Dhamra port site and surrounding areas, Orissa", http://www.greenpeace.org/raw/content/india/press/reports/greenpeacebiodiversity.pdf.

Greenpeace, 2007b, "Summary of Greenpeace response to allegations from North Orissa University and Government of Orissa", http://www.greenpeace.org/raw/content/india /press/reports/email-exchange-onreport/summary-of-greenpeace-response.pdf.

Greenpeace, 2009, “The story so far", http://greenpeace.in/turtle/the-story-so-far.

Hannah, M G, 2011, “Biopower, life and left politics” Antipode 43(4) 1034-1055.

Hawk, E, 2009, “The continuing shame of Orissa” Marine Turtle Newsletter 125 1-3.

Holloway, L and Morris, C, 2012, "Contesting genetic knowledge-practices in livestock breeding: Biopower, biosocial collectivities, and heterogeneous resistances" Environment and Planning D: Society and Space 30(1) 60-77.

Hudson, L, 2011 "A species of thought: Bare life and animal being" Antipode 43, 16591678.

IUCN, 2009, "Dhamra consultative technical workshop, 24-26 February 2009", International Union for Conservation of Nature, http://cmsdata.iucn.org/ downloads/iucn_dhamra_consultative_technical_workshop

IUCN, 2008, "IUCN lighting mission to DPCL, March 2008", International Union for Conservation of Nature, http://cmsdata.iucn.org/downloads/ iucn_lighting_mission_to_dpcl.pdf. 
IUCN, 2007, "Trip report - IUCN mission to Dhamra, India, December 10-17", International Union for Conservation of Nature, http://cmsdata.iucn.org/ downloads/ iucn_dredge_mission.pdf.

Jepson, P and Canney, S, 2003, "Values-led conservation" Global Ecology E Biogeography 12 271-274.

Kay, K, 2012, "High heels and their perennial appeal: Why pain seems a small price to pay" Guardian, http://www.guardian.co.uk/fashion/2012/jul/21/high-heels-stilettosfashion.

Khagram, S, 2004 Dams and development: Transnational struggles for water and power (Cornell University Press, Ithaca).

Kothari, A, 2009, "A sympathetic critique of the Bhaduri-Patkar model" Economic and Political Weekly 44(12) 76-77.

Latour, B, 2004 Politics of nature: How to bring the sciences into democracy (Harvard University Press, Cambridge, Massachussetts).

Lee, C M, Jeong, E H, and Freivalds, A, 2001, “Biomechanical effects of wearing highheeled shoes" International Journal of Industrial Ergonomics 28(6) 321-6.

Lenin, J, 2006, “Vijaya, India's first woman herpetologist" Indian Ocean Turtle Newsletter 4 29-32.

Li, T M, 2007 The will to improve: Governmentality, development and the practice of politics (Duke University Press, Durham and London).

Mansfield, B, 2009, "Sustainability", in A companion to environmental geography Eds N Castree, D Demeritt, D Liverman, and B Rhoads (Blackwell, Malden, Oxford, Chichester), pp 37-49.

Mayr, E, 1997, “The objects of selection” Proceedings of the National Academy of Sciences 94 2091-94.

Mrosovsky, N, 2008, "Continuing controversy over Ridleys in Orissa: Cui bono?" Marine Turtle Newsletter 121 13-15.

MTN, 2008, "Special theme section: Dhamra port development, Orissa, India" Marine Turtle Newsletter 12110 - 33.

Neves, K, 2010, "Cashing in on cetourism: A critical ecological engagement with dominant E-NGO discourses on whaling, cetacean conservation, and whale watching" Antipode 42(3) 719-741.

Palmer, C, 2007, "Ecological intervention in defense of species (online exclusive)" Ethics \& International Affairs 21(3).

Paquet, P C and Darimont, C T, 2010 "Wildlife conservation and animal welfare: two sides of the same coin?" Animal Welfare 19 177-190.

Philo, C, 2012, "A 'new Foucault' with lively implications - or 'the crawfish advances sideways'" Transactions of the Institute of British Geographers 37 496-514.

Porter, J, and Demeritt, D, 2012 “Flood risk management, mapping and planning: the institutional politics of decision-support in England" Environment and Planning A 44 2359-2378. 
Rabinow, P and Rose, N, 2006, “Biopower today" BioSocieties 1 195-217.

Rosser, A M and Leader-Williams, N, 2010, "Protection or use: A case of nuanced trade-offs?", in Trade-offs in conservation: Deciding what to save Eds N Leader-Williams, W M Adams, and R J Smith (Blackwell, Chichester), pp 135-156.

Rutherford, P, 1999, "'The entry of life into history'”, in Discourses of the environment Ed E Darier (Blackwell, Oxford), pp 37-62.

Rutherford, S, 2007, “Green governmentality: Insights and opportunities in the study of nature's rule" Progress in Human Geography 31 291-307.

Sankaran, S, Sridhar, A, and Tripathy, B, 2005 Orissa marine conservation legislation (Ashoka Trust for Research in Ecology and Environment, Bangalore).

Sawicki, J, 1994 “Foucault, feminism, and questions of identity', in The Cambridge companion to Foucault Ed G Gutting (Cambridge, Cambridge University Press), pp 286-313.

Shahabuddin, G and Rangarajan, M eds., 2007 Making conservation work: Securing biodiversity in this new century (Permanent Black, Ranikhet).

Shanker, K, 2001, “Sea turtles and submarines: Sinking the wrong ship?" Kachhapa 4 29-30.

Shanker, K, 2002, “The swampland of sea turtle conservation: In search of a philosophy" Marine Turtle Newsletter (95) 1-4.

Shanker, K, 2003, “What ails the Ridley?” The Hindu, http://www.thehindu.com /thehindu/mag/2003/06/08/stories/2003060800360400.htm.

Shanker, K, 2007, “Deconstructing sea turtle conservation in India", in Making conservation work: securing biodiversity in this new century Eds G Shahabuddin and M Rangarajan (Permanent Black, Ranikhet), pp 81-110.

Shanker, K and Kutty, R, 2005, “Sailing the flagship fantastic: Different approaches to sea turtle conservation in India" Maritime Studies 3(2) 213-240.

Shanker, K, Pandav, B, and Choudhury, B C, 2003, "Sea turtle conservation: Population census and monitoring, A GOI-UNDP project manual", Centre for Herpetology/Madras Crocodile Bank Trust, Mamallapuram.

Shrivastava, A and Kothari, A, 2012 Churning the earth: The making of global India (Viking, New Delhi).

Sridhar, A and Shanker, K, 2007, “Lessons from marine paradigms" Seminar 577 63-68.

Srinivasan, K, 2013, “The biopolitics of animal being and welfare: Dog control and care in the UK and India" Transactions of the Institute of British Geographers 38 106-119.

Wadiwel, D, 2009, "The war against animals: Domination, law and sovereignty" Griffith Law Review 18(2) 283-297.

Warren, C R, 2007, “Perspectives on the 'alien' versus 'native' species debate: A critique of concepts, language and practice" Progress in Human Geography 31(4) 427446.

Wolch, J and Emel, J eds., 1998 Animal geographies: Place, politics and identity in the nature-culture borderlands (Verso, London). 
Wright, B, Mohanty, B, and Matheson, S, 2001, “An update on turtle conservation activities in Orissa" Kachhapa 4 10-13.

Youatt, R, 2008, “Counting species: Biopower and the global biodiversity census" Environmental Values 17 393-417. 